\title{
Väestöpaineen alueittainen muodostuminen ja purkautuminen Suomessa 1950-luvulla
}

Valtiot. kand. ANTTI TUURA

Suunnittelututkimukset ky

Aihe tähän kirjoitukseen on saatu seutu- ja yleiskaavatutkimuksiin liittyneistä väestöselvityksistä. Niin ikään Valtakunnansuunnittelutoimistossa on erinäisissä tutkimuksissa tarkasteltu alueittain väestönmuutoksia ja niissä ilmenneitä eroavuuksia (Strömmer 1960).

Seuraavassa on lähdetty siitä perusajatuksesta, että tilasto- tai talousalueilla - samoin kuin esim. yksittäisissä kunnissakin - ilmenee yhtäältä luonnollisesta väestönkasvusta sekä toisaalta maa- ja metsätalousväestön vähentymisestä koostuvaa väestöpainetta, joka sijoittuu ns. teollisiin eli pääasiassa kaupunki- ja taajamaväestölle tyypillisiin elinkeinoihin. Muodostunut väestöpaine purkautuu omalla alueellaan, maan muille alueille ja ulkomaille.

Väestöpaine, jota tässä nimitetään myös alueella muodostuneeksi lisäväestöksi, käsitetään laajemmin kuin pelkästään väestön luonnollisesta lisäyksestä tai esim. suurista ikäluokista (Strömmer 1957) johtuva paine. Sen moninaiset tekijät on kuitenkin jaoteltu vain mainittuihin kahteen pääryhmään väestön luonnolliseen kasvuedellytykseen sekä maa- ja metsätalousväestön vähentymään - vaikka erittely luonnollisesti voisi olla tarkempikin. Väestön luonnollinen kasvuhan on varsin erilainen maan eri alueilla, muillakin elinkeinoaloilla kuin maa- ja metsätaloudessa on ainakin joissakin kunnissa esiintynyt väestömäärän supistumista jne.

Väestön luonnollisen kasvuedellytyksen arviointiin kaudella 1951—60 on käytetty Väestöpoliittisessa Tutkimuslaitoksessa vuonna 1960 valmistunutta laskelmaa väestön ja työvoiman kasvusta vuoteen 1970 (TuuraPurola 1961). Laskelma perustui vuosien $1951-55$ syntyvyyteen ja kuolevuuteen sekä vuoden 1950 väestölaskennan mukaiseen työhönosallistuvuuteen. Luonnollisen väestönlisäyksen osalta ei ole pidetty tarkoituksenmukaisena ryhtyä mm. peruskaudesta johtuvien epätarkkuuksien poistamiseen tätä karkeislaskelmaa varten. Sen sijaan työhönosallistuneisuuden muuttumisen vaikutus on otettu huomioon ammatissa toimivan väestön kasvuedellytyksiä arvioitaessa.

Maa- ja metsätalousväestön vähentymä samoin kuin muunkin väestön määrässä tapahtuneet muutokset on laskettu vuosien 1950 ja 1960 väestö- 


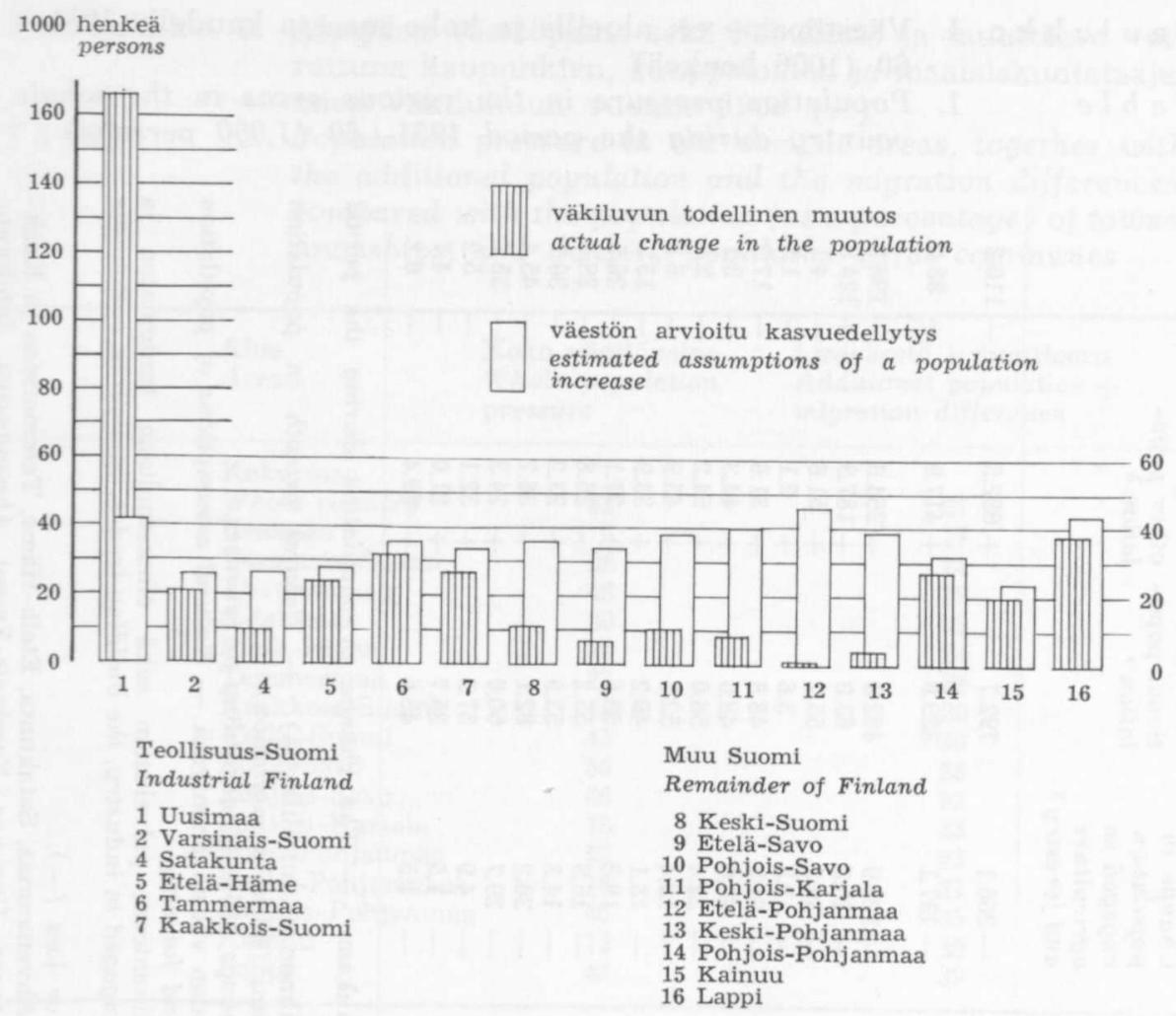

Kuvio 1. Alueiden väestön kasvuedellytys (ilman muuttoliikettä) ja väestön todellinen muutos kaudella 1951-60.

Figure 1. Assumptions of population increase within the various areas (without migration movement) and the actual migration of the population during the period 1951-60.

laskentojen tietojen nojalla. Näihin muutoksiin sisältyy erittelemättömänä $\mathrm{mm}$. koko »itsenäisen ammatittoman väestön» kasvu, joka osaksi johtui tilastointiperusteiden muuttamisesta. - Taulukossa 1 on esitetty alueittain väkiluvun todellinen muutos, laskennallinen (luonnollinen) kasvuedellytys, maa- ja metsätalousväestön muutos, näiden osatekijöiden summa eli käytettävissä ollut lisäväestö sekä muun kuin maa- ja metsätalousväestön yhteismuutos. Viimeisessä sarakkeessa olevat luvut osoittavat alueiden muuttovoittoa tai -tappioita muille alueille ja ulkomaille. — Luvut ovat kaudelta 1951-60.

Alueiden lisäväestön aiheuttaman paineen voitaneen pääasiassa katsoa kohdistuneen kaupunki-, kauppala- ja maaseututaajamiin. Koko väestöpaine ja toisaalta lisäväestön ja muuttoeron $(+/-)$ summa vuoden 1960 
$\mathrm{T}$ a u lukko 1. Väestöpaine eri alueilla ja koko maassa kaudella 195160 (1000 henkeä)

Table

1. Population pressure in the various areas in the whole country during the period $1951-60$ (1,000 persons)
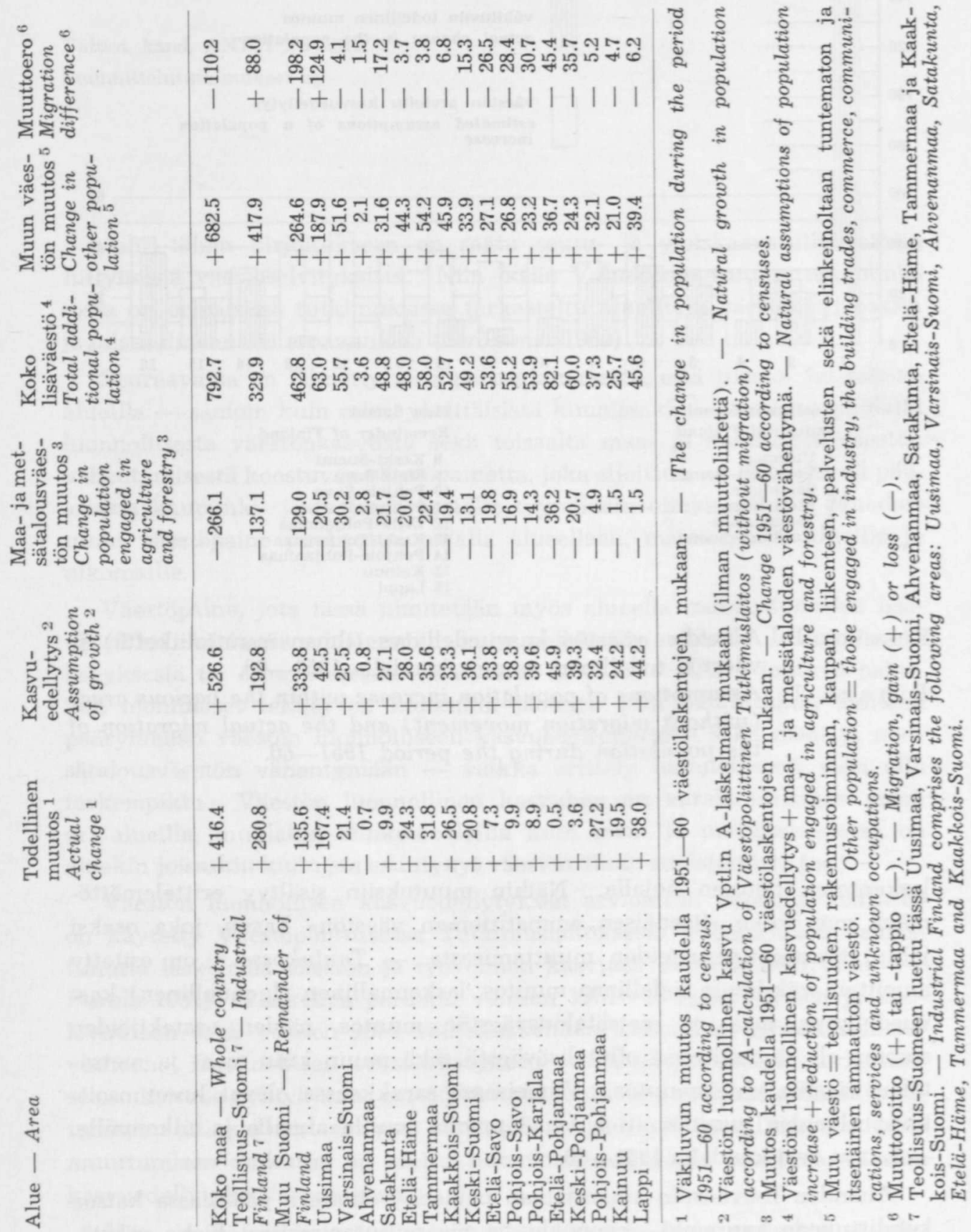
T a u lukko 2. Alueiden väestöpaine sekä lisäväestö ja muuttoero verrattuna kaupunkien, kauppaloiden ja maalaiskuntataajamien väkilukuun vuonna 1960 (\%)

Table 2. Population pressure in the various areas, together with the additional population and the migration differences, compared with the population (as a percentage) of towns, townships, and densely populated rural communes

\begin{tabular}{lcc}
\hline $\begin{array}{l}\text { Alue } \\
\text { Area }\end{array}$ & $\begin{array}{l}\text { Koko väestöpaine } \\
\text { Whole population } \\
\text { pressure }\end{array}$ & $\begin{array}{l}\text { Lisäväestö + muuttoero } \\
\text { Additional population }+ \\
\text { migration difference }\end{array}$ \\
Koko maa & & \\
Whole country & 31 & 27 \\
Uusimaa & 9 & 27 \\
Varsinais-Suomi & 26 & 24 \\
Ahvenanmaa & 48 & 28 \\
Satakunta & 36 & 23 \\
Etelä-Häme & 26 & 24 \\
Tammermaa & 23 & 22 \\
Kaakkois-Suomi & 23 & 20 \\
Keski-Suomi & 43 & 30 \\
Etelä-Savo & 55 & 28 \\
Pohjois-Savo & 66 & 32 \\
Pohjois-Karjala & 76 & 33 \\
Etelä-Pohjanmaa & 52 & 23 \\
Keski-Pohjanmaa & 76 & 31 \\
Pohjois-Pohjanmaa & 40 & 35 \\
Kainuu & 72 & 39 \\
Lappi & 45 & 39 \\
\hline
\end{tabular}

kaupunki- ja kauppalaväestön sekä maaseututaajamien väestön yhteismäärään verrattuna ilmenee taulukosta 2 .

Kaupunkien, kauppaloiden ja maaseututaajamien yhteisväkilukuun verrattuna näyttää väestöpaine olleen vähäisin Uudellamaalla, Tammermaalla, Kaakkois-Suomessa, Varsinais-Suomessa ja Etelä-Hämeessä eli maan teollistuneimmissa ja kasvukykyisimmissä osissa.

Muuttotappioista huolimatta oli alueille 'jäänyt' lisäväestömäärä (lisäväestö + muuttoero) kaupunkien, kauppaloiden ja maaseututaajamien yhteisväkilukuun verrattuna suhteellisen suuri kaikilla niillä alueilla, joilla merkittäviä väestökeskuksia on vähän, eritoten Kainuussa ja Lapissa sekä Pohjois-Pohjanmaalla ja Pohjois-Karjalassakin.

Uudenmaan erikoisasema valtakunnallisena väestöpaineen tasaajana on 1950-luvulla ollut varsin korostunut. Omalla alueellaan oli Uudellamaalla kaudella 1951-60 käytettävissä lisäväestöä, kaikkiaan noin 63000 henkeä, josta luonnollisen väestönkasvun osuus oli noin 43000 . Kun Uudenmaan koko väestönlisäys kaudella 1951-60 kuitenkin oli yli 167 000, muuttovoiton osuudeksi tuli noin $75 \%$. - Lisäväestön yhteismäärästä koko maassa (793000) sijoittui Uudellemaalle $24 \%$, muille alueille $62 \%$ ja ulkomaille 
Taulukko 3. Alueiden lisäväestö ja muuttoero kaudella 1951-60 verrattuina muiden kuin maa- ja metsätalouden väestöön vuonna 1950 sekä näiden elinkeinojen väestönkasvu kaudella 1951-60

Table

3. Additional population in the different areas, and the migration difference during the period 1951-60, compared with population other than those engaged in agriculture and forestry in 1950, and the growth in population of those engaged in these forms of livelihood during the period 1951-60.

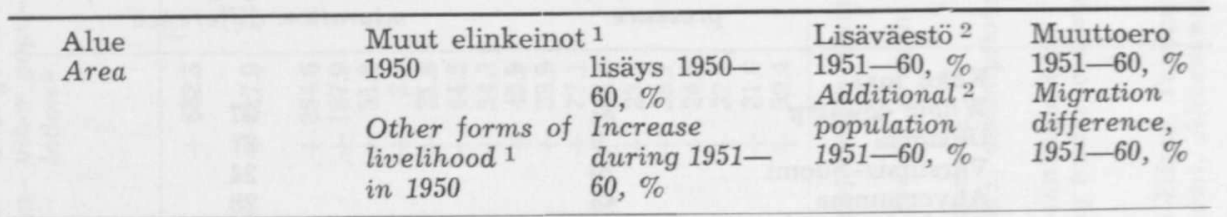

Kokoväestö-Whole population

Koko maa -

Whole country

2355.5

29

Teollisuus-Suomi -

Industrial-Finland

1544.3

27

Muu Suomi -

Remainder of Finland

811.3

Uusimaa

557.1

Varsinais-Suomi

222.6

Ahvenanmaa

11.7

Satakunta

133.2

Etelä-Häme

176.8

Tammermaa

235.3

Kaakkois-Suomi

207.5

Keski-Suomi

113.4

Etelä-Savo

105.1

Pohjois-Savo

90.2

Pohjois-Karjala

Etelä-Pohjanmaa

77.3

169.4

Keski-Pohjanmaa

69.5

75.8

Pohjois-Pohjanmaa

30.7

Kainuu

79.9

\section{3}

34

23

18

24

25

23

22

30

26

30

30

22

35

42

69

49
$-5$

$+6$

$-24$

$+23$

$-2$

$-13$

$-13$

$-2$

$-2$

$-3$

$-13$

$-25$

$-25$

$-40$

$-27$

$-51$

$-7$

$-15$

$-8$

A mmatissa toimiva väestö-Economically active population

Koko maa -

Whole country

1072.3

22

28

$-6$

Teollisuus-Suomi -

Industrial-Finland

730.4

22

13

$+9$

Muu Suomi -

Remainder of Finland $\quad 341.9$

Uusimaa $\quad 284.5$

Varsinais-Suomi $\quad 105.3$

Ahvenanmaa

Satakunta

4.9

57.6

79.2

110.7

Tammermaa

Kaakkois-Suomi

88.2

48.2

44.1

Etelä-Savo

Pohjois-Savo

38.3

30.6

73.2

Etelä-Pohjanmaa

28.7

Keski-Pohjanmaa

32.4

13.1

Kainuu

33.3
23

29

16

14

21

20

17

17

23

15

18

22

13

24

32

50

41
Lappi

58
$-\quad 3$
22
47
23
25
22
24
42
52
58
78
59
96
42
77
49

$-35$

$+26$

$-6$

$-33$

$-2$

$-5$

$-5$

-7
-79

$-19$

$-37$

$-40$

$-56$

$-46$

$-74$

$-10$

$-27$

$-8$ 
maa- ja metsätalouden väestövähentymä $1951-60$

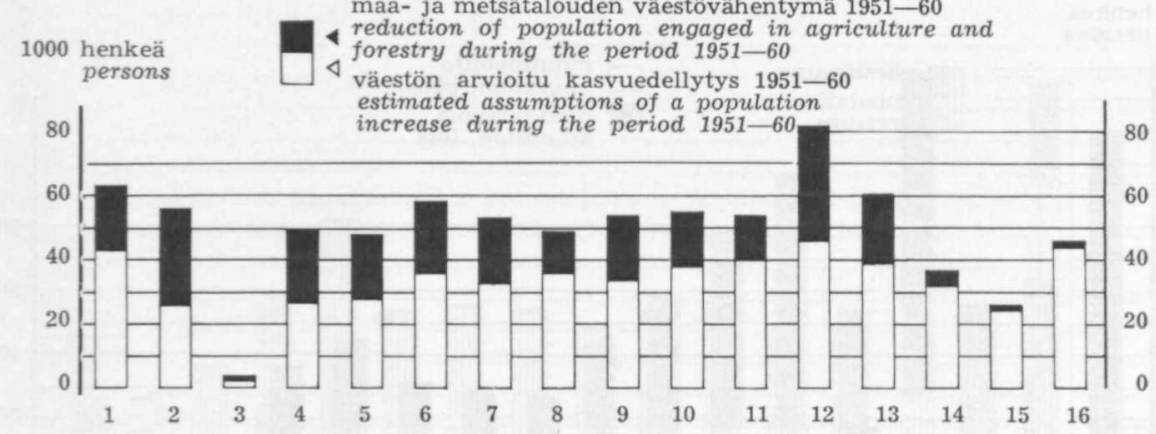

Kuvi o 2. Alueiden väestöpaine kaudella $1951-60$.

Figure 2. Population pressure during the period 1951-60.

$14 \%$. Väestön »ylipainetta» näyttää syntyneen kaikilla muilla alueilla, paitsi Uudellamaalla. Sen määrä oli noin 235000 henkeä ja siitä purkautui Uudenmaan "alipainealueelle» noin $53 \%$ sekä ulkomaille noin $47 \%$. Uusimaa ja viime kädessä sen ydinalue Helsingin seutu on siten varsin tasapäisesti kilpaillut ulkomaiden kanssa suomalaisesta työvoimasta ja väestöstä.

Uudenmaan saama muuttovoitto ja muiden alueiden osaksi tullut muuttotappio antaa aiheen tarkastella käytettävissä olleen lisäväestön sijoittumista teollisiin eli kaupunki- ja taajamaväestölle tyypillisiin elinkeinoihin. Näiden elinkeinojen suhteellinen kasvu (pelkästään väestöllisessä mielessä) eri alueilla jossain määrin selittää lisäväestön alueittaista jakaantumista eli väestöpaineen purkautumissuuntia. Edellytykset lisäväestön hyväksikäyttöön olisivat siten eri alueilla vaihdelleet kyseisten elinkeinojen (teollisuus, rakennustoiminta, kauppa, liikenne ja palvelukset) väestöllisen kasvukyvyn mukaan. - Taulukossa 3 on lisäväestön muodostumista ja sijoittumista tarkasteltu tästä näkökulmasta.

1 Teollisuus, rakennustoiminta, kauppa, liikenne, palvelukset (koko väestössä myös itsenäiset ammatittomat) sekä elinkeinoltaan tuntemattomat.

1 Industry, the building trades, commerce, communications, services (in the whole population, including independent population without profession) and unknown occupations.

2 Väestön luonnollinen kasvuedellytys + maa- ja metsätalouden väestövähentymä (ammatissa toimivasta slisäväestöstäs vähennetty työhönosallistuneisuuden alenemisen arvioitu vaikutus).

2 Natural assumptions of population increase + reduction of population engaged in agriculture and forestry. (From the additional population" engaged in occupations there has been deducted the calculated effect as a reduction of those here engaged in work). 


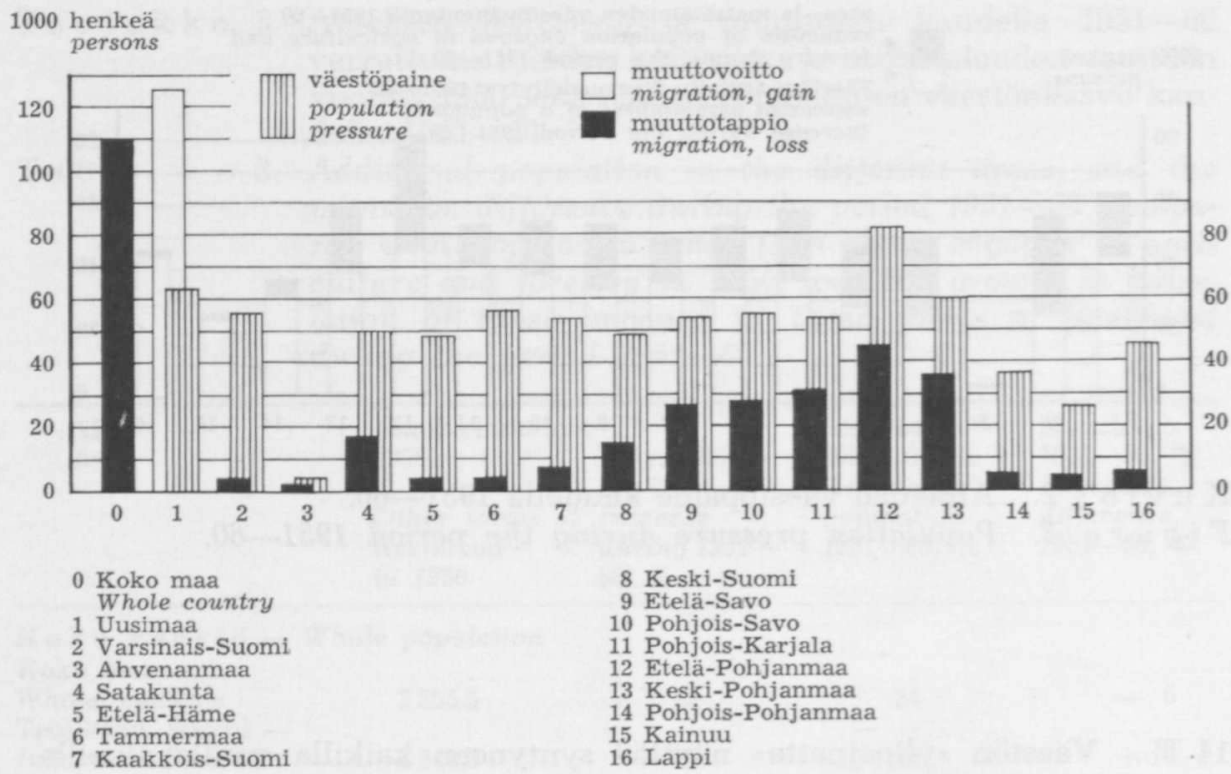

K u vi o 3. Väestöpaineen purkautuminen kaudella $1951-60$.

Figure 3. Eruption of population pressure during the period 1951-60.

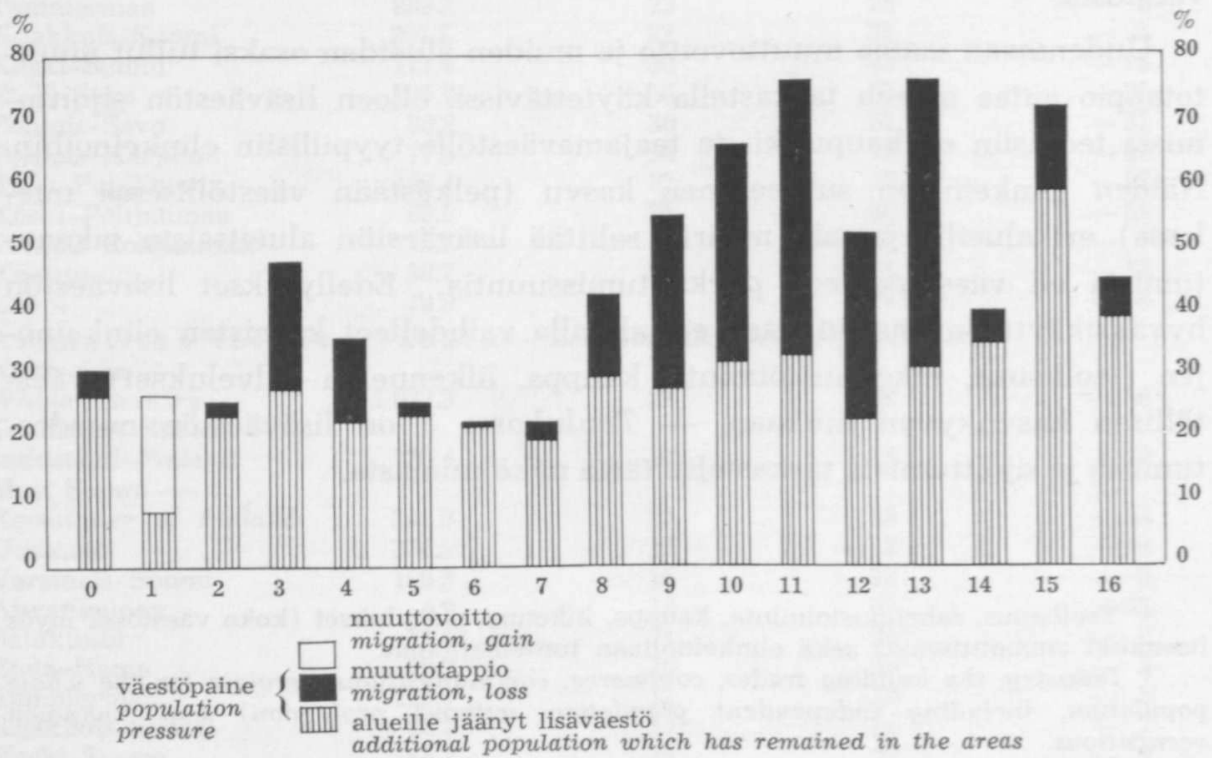

K uvi o 4. Väestöpaine kaudella 1951-60 verrattuna kaupunkien, kauppaloiden ja maaseudun taajamien väkilukuun v. 1960 .

Figure 4. Population pressure during the period 1951-60, compared with the population of towns, townships and densely populated rural communes in 1960. 


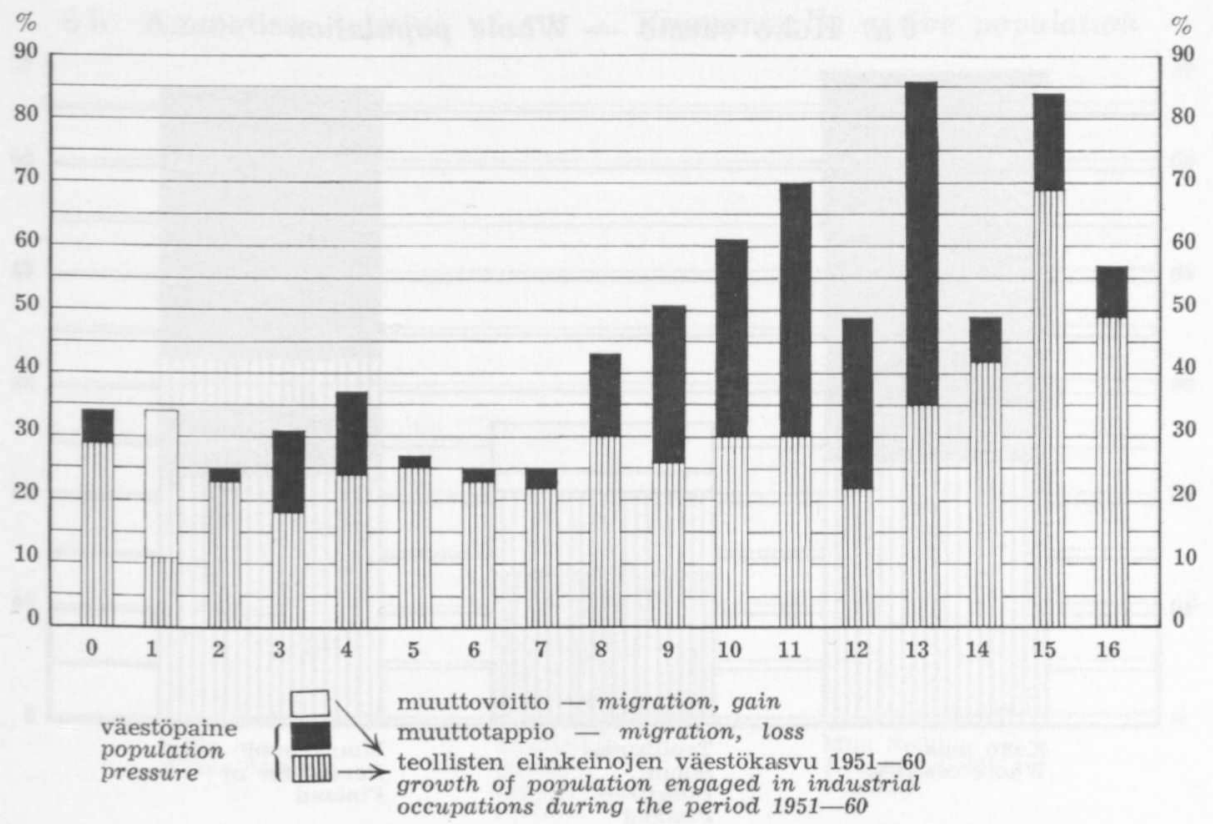

Kuvio 5. Väestöpaine kaudella $1951-60$ teollisten eli kaupunkimaisten elinkeinojen väestöön v. 1950 verrattuna ja näiden elinkeinojen kasvu.

Figure 5. Population pressure during the period 1951-60, compared with the population engaged in industrial, viz. urban forms of livelihood, in 1950, and the development of such forms of livelihood.

Muiden elinkeinojen kuin maa- ja metsätalouden väestö kasvoi koko maassa kaudella $1951-60$ noin $29 \%$. Uuttamaata lukuun ottamatta oli lisäys kaikilla Teollisuus-Suomen alueilla tätä keskimäärää pienempi. Muussa Suomessa sen sijaan tämä suhteellinen kasvu oli keskimääräistä hitaampaa vain Etelä-Savossa ja Etelä-Pohjanmaalla. Suurin suhteellinen lisäys teollisissa ja kaupunkimaisissa elinkeinoissa tapahtui 50-luvulla Kainuussa, missä näiden elinkeinojen koko väestö kasvoi $69 \%$ ja ammatissa toimiva väestö 1.5 -kertaiseksi.

Lisäväestön muodostuminen oli Satakuntaa lukuun ottamatta Teollisuus-Suomessa suhteellisesti heikompaa kuin koko maassa keskimäärin. — Erityisen vähäiseksi se jäi Uudellamaalla, kun taas Muu Suomi kokonaisuudessaan oli keskimäärää paljon suuremman väestöpaineen alaisena. Eroavuuksia ovat tasoittaneet taajamaelinkeinojen nopea kasvu Uudellamaalla ja pohjoisimmilla alueilla (Pohjois-Pohjanmaa, Kainuu ja Lappi) sekä Uudellemaalle ja ulkomaille suuntautunut muuttoliike. Suuri osa Uudenmaan teollisten ja taajamaelinkeinojen laajentumiskyvystä olisi 
6a. Koko väestö - Whole population

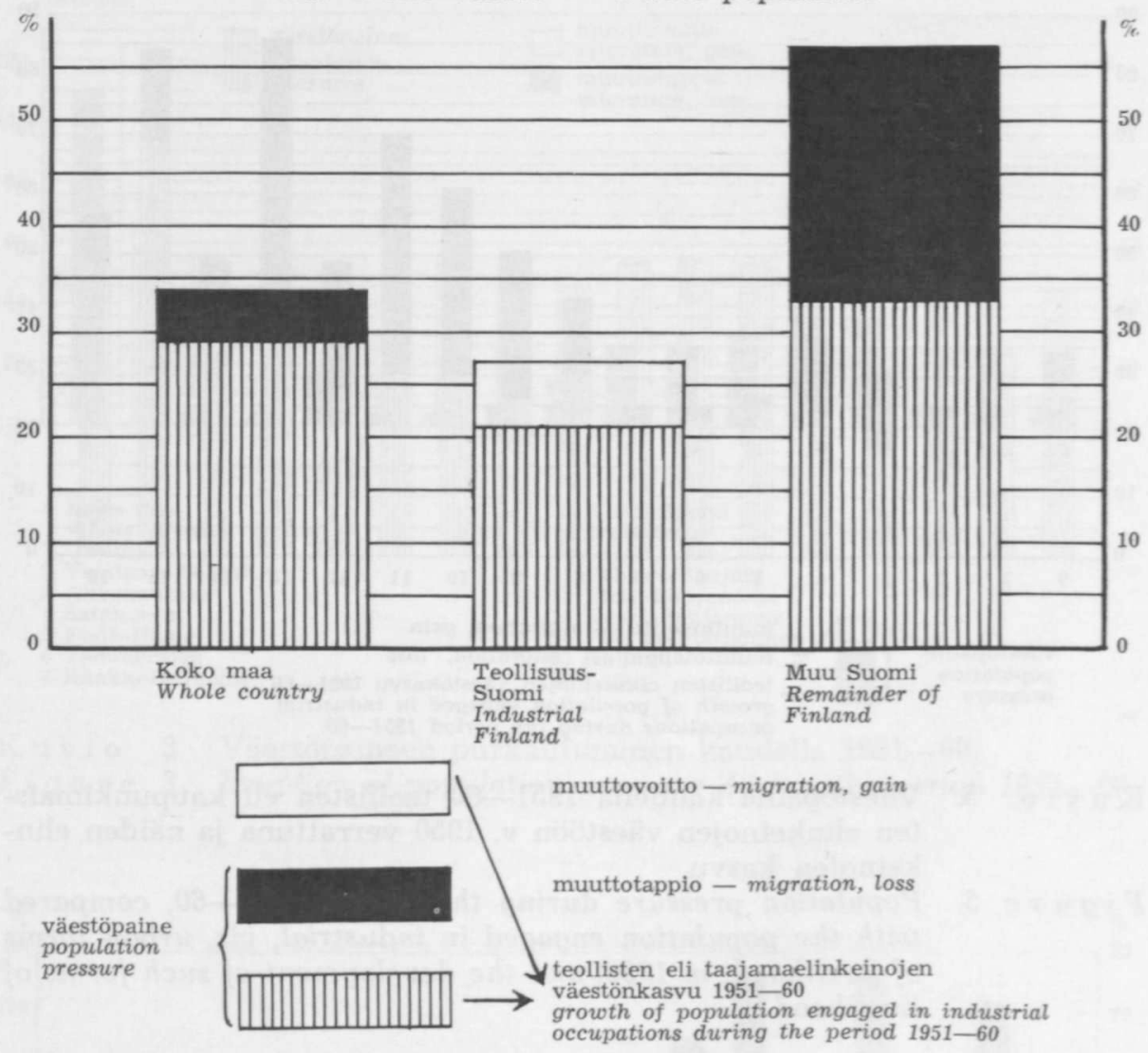

ilmeisesti 1950-luvulla jäänyt ilman muuttoliikettä käyttämättä, sillä työhönosallistuneiden alenemisen vaikutus näyttää tällä alueella jopa ylittäneen ammatissa toimivan väestön luonnollisen kasvun.

Jaettaessa maa Teollisuus-Suomeen ja Muuhun Suomeen voidaan todeta, että maahan jääneen lisäväestön (= muiden elinkeinojen kuin maa- ja metsätalouden väestönkasvu) sijoittuminen oli näin suurissa puitteissa tarkasteltuna samankaltainen kuin kyseisten elinkeinojen väestöjakautuma vuonna 1950:

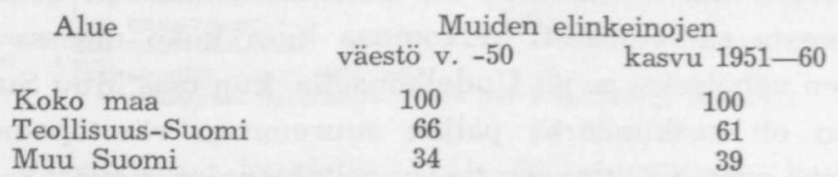

Ammatissa toimivan väestön osalta nämä jakautumat vastasivat vielä tarkemmin toisiaan: 


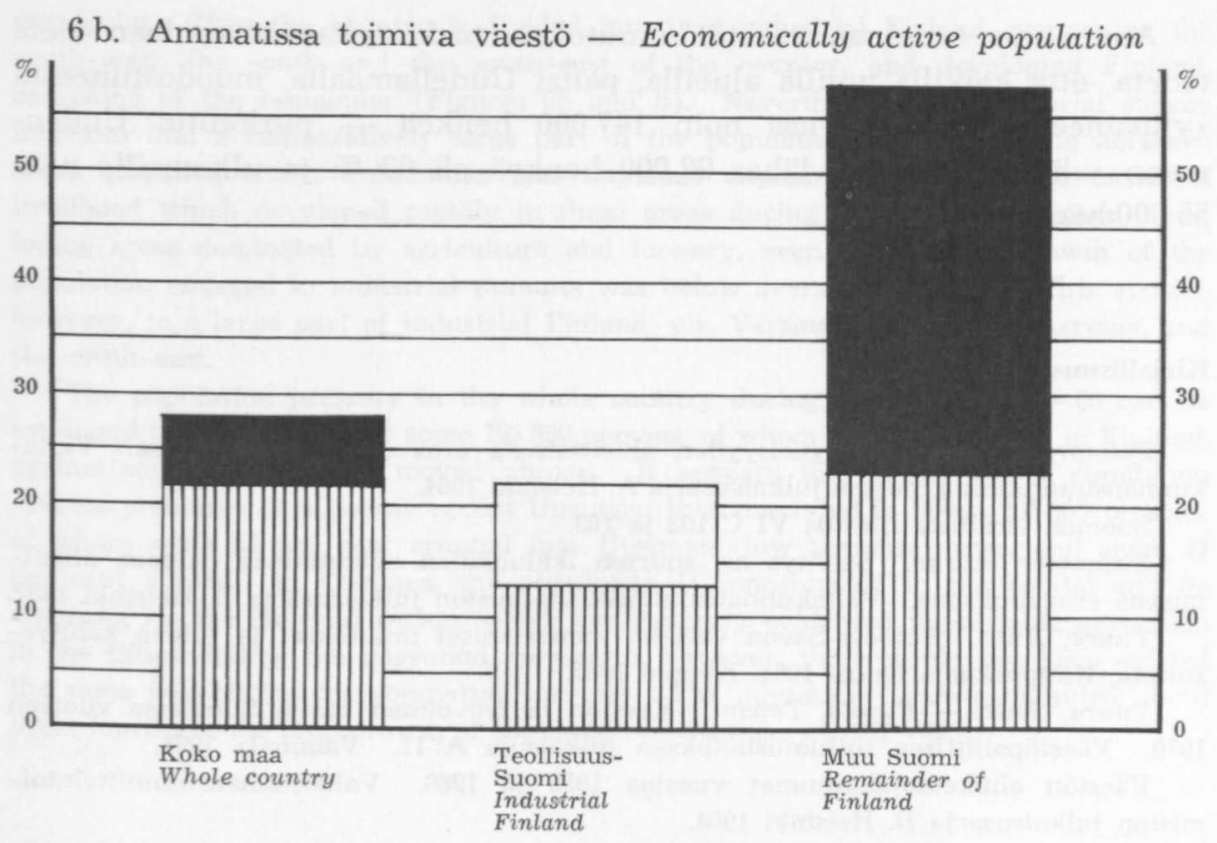

K u vi o 6. Väestöpaine kaudella 1951-60 teollisten eli kaupunkimaisten elinkeinojen väestöön v. 1950 verrattuna ja näiden elinkeinojen kasvu.

Figure 6. Population pressure during the period 1951-60 compared with the population engaged in industrial, viz. urban forms of livelihood, in 1950, and the growth of such forms of livelihood.

Alue

Koko maa

Teollisuus-Suomi

Muu Suomi
Muiden elinkeinojen a.t.väestö v. $-50 \quad$ kasvu $1951-60$

$\begin{array}{rr}100 & 100 \\ 68 & 67 \\ 32 & 33\end{array}$

Mikäli muiden elinkeinojen ammatissa toimivan väestön lisäys kaikilla alueilla olisi vastannut keskimääräistä kasvua koko maassa (22\%) kokonaiskuva ei olisi oleellisesti muuttunut, joskin Uudenmaan ja pohjoisten alueiden osuus lisäväestöstä olisi pienentynyt. Jos taasen tämä taso olisi saavutettu niillä alueilla, jotka jäivät sen alapuolelle, kyseisten elinkeinojen ammatissa toimivan väestön kasvu koko maassa olisi noussut pari prosenttia suuremmaksi, kun taas Uudenmaan muuttovoitto ja maan väestötappio ulkomaille olisivat jääneet pienemmiksi. Lisäväestön sijoittuminen Teollisuus- ja Muuhun Suomeen sen sijaan olisi ollut kutakuinkin sama kuin kaudella $1951-60$ toteutunut jakautuma. 
Ammatissa toimivan väestön muutoksia tarkasteltaessa voidaan vielä todeta, että kaikilla muilla alueilla, paitsi Uudellamaalla, muodostuneesta "ylipaineesta" - yhteensä noin 147000 henkeä - purkautui Uudenmaan "alipainealueelle» lähes 92000 henkeä eli $63 \%$ ja ulkomaille noin 55000 henkeä eli $37 \%$.

\section{Kirjallisuus}

Palmgren, Kai. Kehittyneisyyden alueittaisista eroavuuksista Suomessa. Valtakunnansuunnittelutoimiston julkaisusarja A. Helsinki 1964.

Suomen virallista tilastoa VI C 102 ja 103.

Strömmer, Aarno. Selvitys ns. suurten ikäluokkien aiheuttaman paineen alueittaisista eroavuuksista. Valtakunnansuunnittelutoimiston julkaisusarja B. Helsinki 1957.

Tuura, Antti. Pohjois-Savon väestön viimeaikaiset muutokset ja tuleva kehityssuunta. Kauppakamarivuosi 1964. Kuopio 1965.

Tuura, Antti - Purola, Tapani. Väestön ja työvoiman kasvu Suomessa vuoteen 1970. Väestöpoliittisen tutkimuslaitoksen julkaisuja A: 11. Vammala 1961.

Väestön elinkeinojakautumat vuosina 1950 ja 1960 . Valtakunnansuunnittelutoimiston julkaisusarja B. Helsinki 1964.

\section{Summary:}

\section{The territorial formation and eruption of population pressure in Finland during the 1950's}

\section{By ANTTI TUURA, Suunnittelututkimukset ky}

The author proceeds from the fundamental conception that the population pressure in the fifties in Finland and its various areas was the result of the natural growth of population and the decrease in the population engaged in agriculture and forestry. In the study, this population pressure is also termed the additional population.

The aim of this study was that of ascertaining first of all the extent of the population pressure in the whole country and its various areas, and secondly, that of determining the eruption of the population pressure in the whole country and its various areas. The point of departure for the second part of the study was the eruption of population pressure in the area itself, in other areas of the country and abroad.

By virtue of the natural growth of population and the differences in industrialisation in the various areas, the population pressure during the years $1951-60$ was proportionately smaller in the south-eastern, southern and south-western parts of the country than in other areas dominated by agriculture and forestry (Table 1). The differences occurring in the population pressure, and thus also in the number of additional population pressure, accordingly in the number of additional population present in various areas, was levelled by migration, primarily to Uusimaa and abroad.

The eruption of population pressure seems largely to correspond to the territorial distribution of population engaged in industrial forms of earning a livelihood, i.e. in forms other than agriculture and forestry, if the change is viewed from a territorial 
standpoint. Thus the country is divided into two: industrial Finland, comprising the south-west, the south and the south-east of the country, and developing Finland, consisting of the remainder (Figures 6a and b). Nevertheless, the territorial survey indicates that a comparatively large part of the population pressure in the northern areas (Kainuu, North Pohjanmaa and Lapland) exploded into industrial forms of livelihood which developed rapidly in these areas during the fifties. In other developing areas dominated by agriculture and forestry, even the relative growth of the population engaged in industrial pursuits was below average (Table 3). This applies, however, to a large part of industrial Finland, viz. Varsinais-Suomi, Tammermaa, and the south-east.

The population pressure in the whole country during the period $1951-60$ can be estimated to have comprised some 793000 persons, of whom 683000 remained in Finland, against some 110000 who moved abroad. It appears that there was a population sexcess pressure, in all areas except Uusimaa: this amounted to about 235000 persons, of whom some 53 per cent erupted into Uusimaa »low pressure» area, and some 47 per cent abroad. In Uusimaa, the population is concentrated in the capital and its environs, i.e. the Helsinki region, which consequently evidenced appreciable expansion in the fifties: failing the migration movement, however, there would not have existed the same possibilities for population increase. The migration figure constituted about three fourths of the total growth of population in Uusimaa in 1951 -60 . 